Tomislav Kuzmanović

\title{
Prevođenje po ključu
}

Krajem 2009. godine pisac i urednik Roman Simić Bodrožić kontaktirao me s prijedlogom da napravim nekoliko prijevoda i pošaljem in kao moguće priloge za antologiju pod nazivom Best European Fiction 2012 u izdanju američke izdavačke kuće Dalkey Archive Press. Prijedlog sam, naravno, prihvatio premda mi ovo nije bilo prvi put da šaljem prijevode za spomenutu antologiju. Međutim, moji prijašnji prijevodi nažalost nisu prošli uredničku selekciju te nisu bili uvršteni u prethodna izdanja antologije, odnosno serije antologija čije je prvo izdanje objavljeno 2010. godine, a čiji je urednik priznati američki pisac bosanskog porijekla, Aleksandar Hemon. U njenim prijašnjim izdanjima našli su se tekstovi Nevena Ušumovića, Mime Simić, Igora Štiksa te nekolicine autora s područja bivše Jugoslavije poput Davida Albaharija, Andreja Blatnika, Vladimira Arsenijevića ili Gorana Samardžića, drugim riječima, tekstovi istaknutijih suvremenih pisaca s prostora bivše Jugoslavije koji zajedno s tekstovima drugih europskih pisaca čine vrlo zanimljivu i raznoliku panoramu suvremene književne produkcije u Europi.

Pored samih prijevoda uvrštenih u antologiju, na svojoj internetskoj stranici Dalkey Archive objavljuje intervjue s piscima uključenim u antologiju koji se dotiču stanja na književnoj sceni u nacionalnim književnostima iz kojih autori dolaze te im postavljaju i dva pitanja o prevođenju: Želite li da vaši tekstovi budu prevedeni? Zašto? Zašto ne? i Da možete birati, biste li izabrali doslovan prijevod vašeg djela ili njegovu interpretativnu re-kreaciju? Zašto? Dakle, sve u svemu hvalevrijedan projekt ${ }^{1]}$ i izvanredan tretman prijevoda, sasvim u skladu s misijom Dakley Archivea

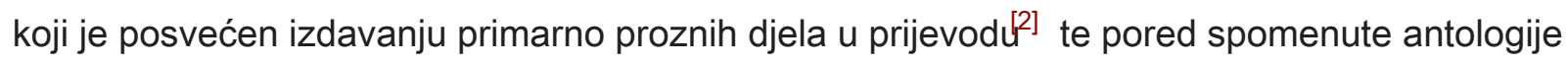
objavljuje edicije nekoliko nacionalnih književnosti u prijevodu (uključujući i naše susjede Slovence) i izdaje časopis Context u kojem se može pronaći vrlo zanimljivih tekstova i rasprava kako o prevođenju, tako i o stanju književnosti u prijevodu u SAD-u, ali i različitim stranim autorima i književnostima. Bez sumnje Dalkey Archive Press mjesto je koje stranim piscima, a onda i njihovim 
prevoditeljima, može poslužiti kao izvrsna odskočna daska i ulaznica u svijet svjetske književnosti ili možda ipak književnosti u prijevodu na jedan od svjetskih jezika.

Nakon što su prijevodi kratkih priča Maje Hrgović i Zorana Malkoča, koje je Roman Simić Bodrožić predložio za prijevod, napravljeni i poslani urednicima u Dalkey Archiveu, uslijedilo je dugo razdoblje iščekivanja, u početku ispunjeno strepnjom i nadom da će rezultati biti brzo objavljeni, no kako je vrijeme odmicalo, nada i strepnja pretvorili su se u pomirenost s tek još jednim neuspješnim pokušajem, a i tu pomirenost postupno je zamijenio zaborav. No, na moje iznenađenje i na e-mail adresu koju sam u međuvremenu prestao koristiti početkom 2011. stigla je prvo obavijest da je moj prijevod kratke priče Maje Hrgović uvršten na širi popis priča koje se razmatraju za antologiju. Već nekoliko tjedana kasnije stigla je i konačna potvrda da će tekst zaista biti objavljen u Best European Fiction za 2012. godinu. Nakon inicijalnog oduševljenja, međutim, pojavilo se pitanje: Zašto baš tekst Maje Hrgović? Zašto baš Zlatka? Pritom je na stvari više bila prevoditeljska želja da oba prevedena teksta budu uvrštena u antologiju. Svojom kvalitetom Zoran Malkoč i Maja Hrgović i njihovi tekstovi to svakako zaslužuju. Međutim, propozicije antologije su takve da je moguće objaviti samo jedan tekst po nacionalnoj književnosti.

Pa ipak, ponajviše ponukan pitanjima o prevođenju i stanju u nacionalnim književnostima koja se postavljaju autorima uvrštenim u antologiju, zapitao sam se koji su kriteriji izbora tekstova za antologiju. Ili, drugim riječima, po kojem su ključu djela izabrana? Možda je to pitanje bila tek posljedica one sumnjičavosti koju prevoditelji iskuse svaki put kad moraju izabrati između dva moguća rješenja u svom prijevodu ili pak onog pitanja koje bi si svaki prevoditelj morao postaviti kad odabire djelo za prijevod: kome je ovo djelo namjenjeno? Što želim da ono komunicira (a komunikacija novih sadržaja, novih spoznaja, novih načina jezičnog izražavanja, pisanja i umjetničkog promišljanja svijeta oko sebe jest primarni cilj i funkcija prevedenog teksta) potencijalnom čitatelju, koja su očekivanja čitatelja, u trenutku izbora djela za prijevod još uvijek imaginarnog, ali svakako prisutnog, i hoće li prijevod izabranog teksta ta očekivanja ispuniti te tako ispuniti očekivanja i nade autora koji je pristao da mu djelo bude prevedeno? I na kraju, što prijevod znači za izvornu književnost i kulturu u cjelini, odnosno, za njezinu sliku u kulturi primateljici? Dakle, radilo se o traženju ključa kojim se dopire do čitatelja, ključa po kojem neko 
djelo bude izabrano za prijevod, a drugo odbijeno, ključa po kojem određeno djelo u prijevodu ulazi u kulturu primateljicu, a drugo ostaje izvan nje.

Po mom mišljenju zapravo je kratka priča Zorana Malkoča Kad sam bio bako Pila, mrtva, a u najboljim godinama imala više šanse da bude izabrana od Zlatke Maje Hrgović ne samo zbog činjenice što je 2008. godine nagrađena književnom nagradom Ranko Marinković, što se činilo kao dodatna referenca koju strani izdavači i urednici često uzimaju u obzir prilikom izbora djela za prijevod i objavljivanje, već i zbog činjenice da se Kad sam bio bako Pila može, a možda i mora, čitati i kao "ratna priča" jer se u njoj, kao i u cijeloj Malkočevoj zbirci Groblje manjih careva u kojoj je priča objavljena, osjeća atmosfera zadnjeg rata na Balkanskom poluotoku i njegovih posljedica. Naime, upravo je takva ratna tematika ${ }^{3]}$ najvećim dijelom prisutna u djelima hrvatske književnosti koja postoje u prijevodu na engleski jezik. Čak će i površno, metodološki ne sasvim vjerodostojno, istraživanje putem Amazona ili neke druge online knjižare-tražilice pokazati naslove i autore koji u svojim djelima dostupnim u prijevodu na engleski jezik na ovaj ili onaj način tematiziraju rat u bivšoj Jugoslaviji i njegove posljedice. To je osobito vidljivo u knjigama Dubravke Ugrešić i Slavenke Drakulić čijih djela ima najviše i koja su najdostupnija u prijevodu na engleski te koja, prije svega svojim brojem i dostupnošću, određuju i zadaju spomenuti ključ po kojem se djela biraju za prijevod.

Posljedice takvog ključa i sâm sam iskusio radeći na jednom od prijevoda na engleski jezik. Radilo se, naime, o prijevodu romana Zorana Ferića Smrt Djevojčice sa žigicama koji se za sve one koji su ga čitali ne može okarakterizirati kao ratni roman. Ako se dobro sjećam kratkih crtica objavljenih na koricama hrvatskog izdanja knjige, Smrt Djevojčice sa žigicama u Hrvatskoj je promovirana kao mediteranski Twin Peaks, dakle, neka vrsta detektivskog romana punog ironije i Feriću omiljene groteske koja ponekad prelazi u karikaturu. Međutim, opis knjige dostupan na Amazonu kaže sljedeće:

U čarobnom okruženju otoka Raba, nasuprot sveprisutnoj tutnjavi artiljerije, u ovoj napetoj priči o politici i psihozi jedan slučaj nasilja stoji nasuprot masovnim ubojstvima koja se događaju drugdje u bivšoj Jugoslaviji. 
Artiljerija, topništvo, politika, psihoza, masovna ubojstva, bivša Jugoslavija ključne su riječi u ovom opisu, ključne riječi koje privlače publiku i prodaju knjigu, odnosno, prevodilačkim rječnikom, približavaju pisca, njegovo djelo, a onda i njegovu književnost, pritom mislim na izvornu književnost, stranoj publici. Prevoditelji na ovakve stvari, na ovakve distorzije jednostavno ne smiju ne pristati; odnosno, smiju, ali tada njihov prijevod i njihov autor ostaju neobjavljeni i svakako gube određeni broj čitatelja. Naprosto, htjeli mi to priznati ili ne, takvo je stanje stvari. Možda se ovdje, riječima Itamara Evena-Zohara i Gideona Touryja, radi o izboru između adekvatnosti (adequacy) i akceptabilnosti (acceptability), između podudarnosti i prihvatljivosti. Dakle, prihvatljivo je u ovom slučaju pomalo iskriviti činjenice, ili pristati na takvo iskrivljavanje činjenica, zamotati knjigu u ponešto drukčije korice, naravno, ako će to ispuniti jednu od svrha prevođenja: uvesti autora u drugu, stranu kulturu i osigurati mjesto za njegovu knjigu u stranoj knjižari ili knjižnici.

Važno je ipak naglasiti da se u ovom slučaju nije radilo o intervenciji u tekst, prijevod se nije iznova upisivao (re-writing) "kako bi se promijenili događaji ili njihov slijed. I nijedan od postupaka likova nije izbrisan ili izmijenjen. Datumi, povijesni i zemljopisni markeri, imena likova [...] ostali su isti” (Venuti 2000: 470). Isto se dogodilo, u onoj mjeri u kojoj je to moguće u prijevodu, s autorskim glasom kao i stilskim i poetičkim obilježjima knjige. Ovdje je na djelu zaista bilo tek "pakiranje", odnosno, doslovno omot knjige i popratni tekst o knjizi. Naravno, valja priznati da je i ovo manipulacija, da je i ovo upisivanje djela u kulturu primateljicu čime su neka od obilježja (možda tek reklamiranja i predstavljanja, ali i oni su sastavni dio knjige kao proizvoda, a u nekim slučajevima i umjetničkog objekta) izvornika izgubljena. No, ne gubi li se uvijek nešto u prijevodu? Također treba reći da je ovakva manipulacija učinjena svjesno, da su na nju pristali svi uključeni akteri (ako izuzmemo publiku i kritičare koji "padaju" na korice), da je njome zapravo "izigran" sistem, odnosno iskorištena prilika da autor i njegovo djelo postanu što dostupniji i čitaniji.

Kratkoj priči Maje Hrgović, na prvi pogled, nije prijetila takva opasnost, dakle, opasnost da upadne u kategoriju ratnih priča s određenim ideološkim predznakom. Zlatka je "ženska" priča lezbijske tematike koja govori o dvije žene - frizerki i pripovjedačici - koje se slučajno sretnu u jednom frizerskom salonu, a potom i u noćnom klubu te provedu noć zajedno. Mjesto radnje je grad Zagreb, točnije njegov uži centar, prostor oko Glavnog kolodvora te Novi Zagreb i jedan od njegovih nebodera. Ni riječi o politici, ratu, artiljeriji, masovnim ubojstvima, o bivšoj Jugoslaviji 
(osim možda u činjenici da u noćnom klubu te večeri glazbu pušta DJ Krš iz Srbije) i drugim elementima koji bi mogli biti privlačni američkim urednicima, izdavačima i čitateljima. Zlatka je priča izuzetno snažnog autorskog glasa, snažnih emocija, dojmljive atmosfere i razrađenih likova, jednom riječju, vrlo kvalitetna kratka priča perspektivne i talentirane mlade autorice. Ovdje se, dakle, radilo prije svega o kvaliteti djela, literarna vrijednost ove priče bila je ključ po kojem je izabrana u antologiju. I činilo se da sam kao prevoditelj uspio napraviti "čist" posao: prevesti priču i upisati je u drugi jezik i drugi kontekst u kojem ona može funkcionirati bez manipulacije bilo kojim od elemenata njezina sadržaja. Činilo se da je ovo prijevod koji se neće čitati ni u kojem (nametnutom, isforsiranom, izmanipuliranom, ponovno upisanom, re-inskribiranom) ključu, već u onom ključu u kojem je priča izvorno napisana.

Ponovni pogled na djela hrvatske književnosti dostupna u prijevodu na engleski jezik, međutim, otkriva prijevode djela Dubravke Ugrešić i Slavenke Drakulić koja, uvjetno rečeno, spadaju u kategoriju "ženskog" pisma ili se barem udaljavaju od gorespomenute "ratne" proze koja dominira njihovim opusom u zadnjih desetak godina te predstavlja ono po čemu su najprepoznatljivije kako stranoj tako i domaćoj publici. Dakle, u opusu, uz Predraga Matvejevića, dviju najprevođenijih i najpoznatijih hrvatskih autorica, kad su prijevodi na engleski jezik u pitanju, u posljednjih nekoliko godina vidljiv je zaokret i odmak od sadržaja i tema koje su problematizirale u svojim dotadašnjim djelima ${ }^{[4]}$ te se stoga ne može ne prepoznati ili barem nazrijeti "ključ" po kojem je kratka priča Maje Hrgović uvrštena u antologiju Best European Fiction 2012. Dakle, Zlatka nije uvrštena u antologiju (samo) zato što je primjer kvalitetne književnosti s ovih prostora koja donosi nešto novo u kulturu primateljicu, već zato što odgovara i uklapa se u unaprijed zadanu kategoriju i, barem kad su SAD i angloamerička kultura u pitanju dominantno, viđenje ovog prostora, njegove kulture i književnosti. Hrvatska književnost, ako je suditi po djelima koja su dostupna i koja se odabiru za prijevod na engleski jezik, spada upravo u takvu kategoriju, u taj i takav ključ: rat ili žensko pismo ili, ako je moguće, kombinacija jednog i drugog.

Međutim, bilo bi pogrešno prozivati Slavenku Drakulić i Dubravku Ugrešić zbog ovakve situacije (nisu li, uostalom, u našoj sredini već dovoljno prozivane?) ili umanjivati vrijednost njihova opusa i uspjeha u angloameričkoj kulturi. One naprosto pišu književnost - sviđala se ona kome ili ne, sasvim je nevažno - koja ima uspjeha kod ciljane publike. Razloge ovakvoj situaciji, ovakvoj 
negativnoj "selekciji" koja ne dopušta novine, već traži i propušta samo ona djela koja na ovaj ili onaj način spadaju u unaprijed zadanu kategoriju (ili in se manipulacijom, kao što je vidljivo u spomenutom primjeru prijevoda romana Zorana Ferića, u tu kategoriju može smjestiti) treba tražiti drugdje.

Razlozi možda leže u komercijalizaciji kulture i književnosti, u beskrupuloznom biznisu u koji se izdavaštvo pretvorilo a koji diktira potražnja koja onda diktira i ponudu. Dakle, radi se o tome da se kroz ovakvu kategorizaciju i tretman hrvatske književnosti publici jednostavno nudi ono što ona traži. Bez ulaženja u psihologiju konzumenta, može se reći da publika traži ono što poznaje ili barem ono o čemu ima kakve-takve spoznaje, a to je, u slučaju hrvatske kulture, ratna tematika i budući da su dvije najpoznatije i najcjenjenije hrvatske spisateljice pokušale proširiti svoju ponudu dodatnim sadržajima - žensko pismo. Djela izvan ovih kategorija vrlo će teško pronaći put do tržišta, do knjižara i publike, što izdavačima, uz ionako goleme probleme s plasmanom prijevoda, predstavlja velik problem te je ekonomski neisplativo.

Nadalje, razlozi za ovakvu situaciju i ovakav tretman prijevoda djela hrvatske književnosti na engleski jezik mogu se pronaći i u, uvjetno rečeno, postkolonijalnom pristupu prijevodima, odnosno, hegemonističkom tretmanu hrvatske književnosti kako općenito tako i u prijevodu. Kao što kaže Richard Jacquemond u knjizi Douglasa Robinsona Translation and Empire: Postcolonial Theories Explained:

potlačena kultura će u hegemonističkoj kulturi biti predstavljena prijevodima koji su (1) brojem daleko manje zastupljeni od svojih pandana u suprotnom smjeru, (2) percipirani kao teški i od interesa samo specijaliziranim stručnjacima, (3) izabrani zbog svog konformizma s hegemonističkim stereotipima i (4) često napisani upravo s ciljem konformiranja takvim stereotipima i stoga prevedeni i čitani u hegemonističkoj kulturi. Hegemonistička kultura, s druge strane, bit će predstavljena u potlačenoj prijevodima koji su (1) brojem daleko više zastupljeni od svojih pandana u suprotnom smjeru, (2) percipirani kao istinski zanimljivi širokoj čitalačkoj publici, (3) izabrani zato što dolaze iz hegemonističke kulture i (4) tipično napisani bez ikakvog poznavanja potlačene kulture.

(Robinson 1997: 32) 
Naravno, iluzorno je očekivati da će djela hrvatske književnosti biti zastupljena u prijevodu na engleski jezik jednakim brojem prijevoda kao djela američke ili angloameričke književnosti u prijevodu na hrvatski. Radi se naprosto o različitim veličinama književnosti, a osim toga jasno je da su danas djela američke ili angloameričke književnosti najzastupljenija i u korpusu svjetske književnosti. No ove druge elemente, osobito ako se u obzir uzme već spomenuta ideološka pozadina koja se dade iščitati iz opusa najprevođenijih hrvatskih autorica i inzistiranje na, uvjetno rečeno, demokratičnosti, anacionalnom ključu ili pak inzistiranje na civilizacijskom iskoraku koji se suprotstavlja svakoj vrsti nacionalizma ili, točnije, svaku vrstu patriotizma automatski pretvara u nacionalizam, svakako valja uzeti u obzir. Naime, ako se na trenutak poželimo poigrati teorijama zavjere, možemo reći da se na engleski jezik prevode djela već spomenute "ratne" tematike upravo zato što tematiziraju raspad jednog multinacionalnog, multikulturalnog, multijezičnog eksperimenta, inzistiranja na zajedništvu unatoč različitostima, itd. te kao takva mogu poslužiti kao "upozorenje" protiv mogućih previranja u SAD-u. Isto tako, inzistiranjem na ovakvoj tematici, odnosno, zazivanjem zapadnog ideala slobode, civiliziranosti i demokratičnosti, ovakva djela u potpunosti odgovaraju i podupiru te, u određenom smislu, reflektiraju načine na koje dominantna kultura vidi sebe, dakle, kao ideal slobode, civiliziranosti i demokracije. Međutim, ovakvo objašnjenje valja uzeti s velikom rezervom i priznati da se ovdje ipak radi o mogućem prevelikom učitavanju u problem s kojim se ovdje suočavamo.

Isto tako, kao jedan od mogućih razloga ovakvog stanja možemo spomenuti i nepostojanje čitateljske zajednice - prije svega znanstvenika i specijalista, a onda i dovoljno informiranih kritičara - koja bi mogla poslužiti kao svojevrstan korektiv ovakvog stanja te prozvati i, ako je potrebno, prokazati posljedice ovakve neadekvatne selekcije po prezentaciju i recepciju izvorne književnosti u stranoj kulturi. S druge strane, ta bi zajednica također mogla postojeću situaciju i blagosloviti, odnosno, ovjeriti. Za razliku od primjera s prijevodima talijanske poezije i talijanskom akademskom zajednicom u SAD-u koji navodi Venuti (2000: 478), u SAD-u ne postoji snažan akademski centar koji bi se bavio hrvatskom književnošću (makar i u širem kontekstu bivše jugoslavenske ili istočno-europske književnosti ili čak u sklopu neke od postojećih slavistika), štoviše, ne postoji, s izuzetkom nekoliko programa na sveučilištima u sklopu kojih se poučava hrvatski jezik i tek nekolicine znanstvenika koji se bave kulturom i književnošću ovog dijela svijeta, 
nijedan program orijentiran na književnost. Utjecaj hrvatskih znanstvenika, kritičara i prevoditelja ili pak samih autora na zbivanja u stranoj kulturi i književnosti u koje su njihova djela prevedena ne postoji, a i da postoji, pitanje je kakav bi bio njegov učinak i bi li taj utjecaj također imao negativne posljedice prije svega po pitanju čitanosti djela koja postoje u prijevodu. Naprosto, valja priznati da način na koji hrvatski čitatelji i kritičari vide određeno djelo hrvatske književnosti te motivi, teme i sadržaji koje oni smatraju kvalitetnima ne moraju odgovarati viđenju djela i njegove kvalitete u stranoj kulturi.

Međutim, u SAD-u ili u angloameričkom kulturnom krugu ipak postoji zajednica na koju su takvi prijevodi usmjereni. Broj članova te zajednice, broj recipijenata ove književnosti limitiran je i određen prije svega njihovim spoznajama - koje neminovno za sobom povlače, kao što je već rečeno, potencijalno hegemonističke, predrasude - u političkom, geografskom i kulturološkom smisli[ ${ }^{[5]}$. Takva, brojem, spoznajama i informacijama limitirana zajednica, ima i limitiranu moć čitanja ponuđenih im djela. Naime, djela se čitaju samo u danom ključu jer ne postoje drugi prijevodi koji bi omogućili neki drugi ključ čitanja ili pak promjenu tog ključa a samim time i promjenu načina viđenja izvorne kulture i konteksta. Također, ne postoji ni interes za promjenom. Premda postoji čitateljstvo - radi li se ovdje o potpuno stranim čitateljima koji ni na koji način nisu vezani za ovaj geografski i kulturni prostor ili pak čitateljima iz redova hrvatske ili bivše jugoslavenske dijaspore ${ }^{[6]}$ nije toliko važno - koje čini zajednicu na koju su prijevodi hrvatske književnosti u prijevodu usmjereni i koja ima interes za čitanje takve književnosti, takvi "interesi koji povezuju zajednicu kroz prijevod ne fokusiraju se samo na strani tekst, već u sebi reflektiraju domaće vrijednosti, vjerovanja i reprezentacije koje prevoditelj u prijevod upisuje" (Venuti 2000: 477). Drugim riječima, kao što je već nekoliko puta rečeno, djela hrvatske književnosti prevedena na engleski jezik odgovaraju sklopu vrijednosti i vjerovanja književne publike, odnosno, u ovom slučaju, zajednice koju čine i izdavači i prevoditelji, a onda posljedično i autori, na koju su ta djela usmjerena. Takva situacija kao posljedicu ima nesrazmjer između onoga što je dostupno u prijevodu i, uvjetno rečeno, stvarnog stanja u izvornoj književnosti. Može se reći da je u prijevodu djela hrvatske književnosti na engleski jezik vidljiv: 
[K]omunikacijski jaz [...] između strane i domaće kulture. Domaća inskripcija u prijevod čini strani tekst privlačnijim masovnoj publici u drugoj kulturi. Ali širenje opsega domaćeg znači da inskripcija ne uključuje mnogo od stranog konteksta. Prevedeni bestseler riskira redukciju stranog teksta na ono što je zajedničko domaćoj publici: dijalekt, kulturni diskurs, ideologija.

Venuti 2000: 482

Dakle, ovdje se radi o stranom a domaćem, stranom koje ispunjava domaća očekivanja bilo u jezičnom, kulturološkom, ideološkom ili političkom smislu te je stoga uspješno kako u komercijalnom, tako i u drugim smislovima. Može se, nadalje, zaključiti da je ovakva situacija posljedica podomaćivanja (domestication, Venuti) u prijevodu, odnosno, upisivanja domaćeg u strano radi bolje i lakše recepcije i percepcije u domaćoj kulturi:

Dominacija podomaćivanja koja inzistira na tečnosti prijevoda omogućava ovakav razvoj situacije zbog svoje ekonomske vrijednosti: nametnuta od strane urednika, izdavača i kritičara, fluentnost prijevoda kao posljedicu ima prijevode koji su prije svega lako prohodni i stoga isplativi na književnom tržištu, što pospješuje njihovu komodifikaciju i osigurava zanemarivanje stranih tekstova i diskursa koji postoje u prijevodu na engleski jezik koji pokazuju više otpora prema lakoj čitljivosti.

Venuti 1995: 16

Međutim, valja napomenuti da se ovdje ne radi o podomaćivanju u onom užem smislu, dakle, o podomaćivanju i upisivanju domaćih vrijednosti (jezičnih, stilističkih, poetoloških, kulturoloških, ideoloških, itd.) u tekst prijevoda, odnosno u samo tkivo stranog teksta, već o podomaćivanju na višoj razini, na razini izbora djela za prijevod, na razini njegove selekcije, kategorizacije, recepcije i percepcije. U nekoliko svojih djela Lawrence Venuti govori o podomaćivanju i njemu suprotstavljenom postranjivanju (foreignization), otporu etnocentričkom nasilju nad stranim tekstom, fokusirajući se na tekst prijevoda i prevoditelja kao najvažnijeg aktera u ovom procesu koji svjesno ili nesvjesno, znajući ili ne znajući, (najčešće, čini se, ovo drugo) manipulira tekstom i u njega upisuje vrijednosti domaće kulture. Međutim, u prijevodu kratke priče Maje Hrgović - za razliku od teksta Mime Simić objavljenog, najblaže rečeno, u potpuno "izmasakriranom" obliku u 
prethodnom izdanju antologije - pa čak i unatoč kasnijim uredničkim intervencijama, po mom mišljenju, nema elemenata podomaćivanja. Barem ne u smislu etnocentričkog nasilja nad stranim tekstom od strane samog prevoditelja.

Ovdje se, dakle, ne radi o podomaćivanju u sklopu čina prevođenja već o podomaćivanju u sklopu široko shvaćenog procesa prevođenja. Najjednostavnije rečeno, čin prevođenja podrazumijeva rad na prijevodu, postupak stvaranja prijevoda u kojem prevoditelj djeluje sam. Ovu "samostalnost" ili neovisnost prevoditelja od vanjskih čimbenika, naravno, ipak treba shvatiti uvjetno jer prevoditelj sa sobom nosi iskustvo kulture za koju i iz koje prevodi djelo, iskustvo pisanja prijevoda, iskustvo čitanja književnih djela napisanih na jeziku na koji prevodi i s kojeg prevodi, kao i iskustvo brojnih nepročitanih djela napisanih na tim jezicima, a koja se reflektiraju i svoje tragove imaju u pročitanim djelima ili su naprosto dio kulturnog naslijeđa i obrazovanja prevoditelja. S druge strane, proces prevođenja, za razliku od čina prevođenja koji je njegov sastavni dio, započinje izborom djela za prijevod, a završava njegovim objavljivanjem, odnosno životom u kulturi primateljici i posljedicama koje taj život ima kako na izvorno djelo i njegova autora tako i na samu izvornu književnost i kulturu. Prilikom izbora djela za prijevod i njegova objavljivanja, prevoditelju asistiraju, ponekad, kao što pokušavam pokazati na primjeru prijevoda kratkih priča Maje Hrgović i Zorana Malkoča, i diktiraju što će i kako prevoditi, urednici, odnosno izdavačke kuće svojom ponudom da napravi prijevod, kao i mnogi drugi više ili manje važni čimbenici poput književnih kritičara ili pak već prevedenih djela i autora koji mogu služiti kao putokaz prilikom izbora djela za prijevod, odnosno odrediti kategoriju ili pak više puta spomenuti ključ po kojem se odlučuje koje će djelo biti izabrano za prijevod. Ovdje, dakle, pored kriterija od kojih je estetska ili literarna kvaliteta djela tek jedan od čimbenika, možemo govoriti o već spomenutim političkim, ideološkim, kulturološkim, književnim i neknjiževnim, društvenim i mnogim drugim čimbenicima koji često imaju važniju ulogu od estetske kvalitete djela.

U datoj situaciji, na razini procesa prevođenja, odnosno onog segmenta prevođenja koji nije izravno u vezi s prevoditeljem, već mu na određeni način izmiče iz ruku te na njega prevoditelj, baš kao i izvorni autor, ne može utjecati, sasvim je logično i razumljivo da priliku za objavljivanje na engleskom jeziku dobivaju samo ona djela koja odgovaraju spomenutom ključu, koja dobro kotiraju kod književne zajednice na koju su usmjerena, koja su ekonomski isplativa i vrijedna ili pak koja 
odgovaraju ideološkim predrasudama čak i ako se u određenom trenutku glavne karakteristike tog ključa - u slučaju hrvatske književnosti usredotočenog na spomenutu ratnu tematiku - za trenutak promijene, odnosno, kada se tematsko, ideološko, poetološko, političko, itd. polje za trenutak proširi i u sebe pripusti ponešto drukčije motivsko-tematske sadržaje koji su, međutim, ipak ovjereni pa stoga i prihvatljivi jer za njih potvrdu možemo pronaći u, uvjetno rečeno, kanoniziranim spisateljicama i njihovim bibliografijama. Drugim riječima, postojeći prijevodi djela hrvatske književnosti na engleski jezik, prijevodi kojima dominiraju spomenuta tematska polja, na određeni način bivaju kanonizirani, takvi su prijevodi postali općeprihvaćeni i razumljivi kanon koji predstavlja hrvatsku književnost u prijevodu, ali kroz koji se istovremeno i gleda svako novo djelo koje u taj kanon pokuša ući. U taj se kanon ne mogu probiti djela drukčije tematike, odnosno, djela koja se na ovaj ili onaj način u njega ne mogu uklopiti ili ga barem ne podupiru i održavaju.

Sada se nameće pitanje koja je posljedica ovakvog stanja. lako je iluzorno očekivati da je bilo koja književnost u prijevodu zastupljena u potpunosti, odnosno, da u prijevodu na strani jezik postoje djela koja mogu ponuditi presjek cjelokupne suvremene književne produkcije neke nacionalne književnosti ili da se razvoj i kontinuitet zbivanja na nekoj nacionalnoj književnoj sceni mogu pratiti s kakvom-takvom recentnošću, u slučaju hrvatske književnosti u prijevodu na engleski jezik, osobito u slučaju kanonizirane, očito je vrlo veliko odstupanje od stvarnog stanja u hrvatskoj književnosti. Naravno, odstupanje i određeni odmak kod književnosti u prijevodu uvijek postoje nemoguće je očekivati da će sva djela biti prevedena niti sva djela mogu biti prevedena na strani jezik; neka su, naprosto, svojim sadržajem, jezikom, itd. previše lokalna i možda uopće nisu upućena na stranu publiku ${ }^{[7]}$ - no dominantni trendovi na recentnoj hrvatskoj književnoj sceni ipak upućuju na ponešto drukčiju situaciju od one koju imamo u prijevodu. Ne može se reći da hrvatskom književnom scenom dominira isključivo ratna tematika, a premda se možda ipak može, barem ako je suditi po posljednjoj književnoj godini, primijetiti dominacija ženskih autorica, ipak je teško povjerovati da je poklapanje domaće i prijevodne situacije na primjeru Maje Hrgović tek više od slučajne podudarnosti.

Nadalje, ovdje se radi o nemogućnosti adekvatne valorizacije prevedenog teksta, odnosno vrijednost teksta Maje Hrgović ne može se adekvatno ocijeniti zato što se on ne može ni pročitati u pravom kontekstu jer je kontekst takav da je hrvatska književnost - doduše, samo u prijevodu, ali 
prijevodi su slika stanja na izvoru, ili bi to trebali biti - barem kad je u pitanju broj dostupnih prijevoda recentnih djela, a to je, ne smijemo biti u zabludi, sve što i spomenuti malobrojni stručnjaci (naravno, ne oni iz Hrvatske, premda oni iz Hrvatske znaju malo o stanju svoje književnosti u prijevodu) znaju o hrvatskoj književnosti, ograničena na kontekst "ratne" književnosti. Spomenuto podomaćivanje na višoj razini, odnosno, podomaćivanje prilikom selekcije, kategorizacije, percepcije i recepcije djela u kulturi primateljici ili pak, kao što to navode Lefevere i Bassnett, ponovno upisivanje (re-writing) određenog djela u kulturu primateljicu, odnosno, manipulacija njime pod utjecajem različitih hegemonistički obilježenih čimbenika, omogućeni su veličinom književnosti, odnosno, prema Even-Zoharu njenim položajem unutar polisistema prijevodne književnosti. Naime, književnost u prijevodu s hrvatskog jezika, ako ne i književnost u prijevodu općenito, ima rubnu poziciju u polisistemu angloameričke književosti te je stoga, kako u činu prevođenja (osobito ako se radi o stranim, ne-hrvatskim prevoditeljima) tako i u procesu prevođenja, izložena prihvaćanju nametnutih, ali možda već i u domaćem polisustavu odbačenih normi. Dakle, da pojasnim, prevode se ona djela koja na određeni način već postoje u polisistemu, odnosno, ona djela koja već imaju utvrđeno mjesto u sustavu i ni na koji način u njemu ne pokušavaju narušiti ravnotežu ili uspostavljenu hijerarhiju. Na taj način, takva djela podržavaju domaći sustav, u njega, načelno, ne unose ništa novo, istovremeno sprečavajući da novina iz strane književnosti prodre u domaći sustav i izazove promjenu. Premda bi strana književnost, odnosno, književnost u prijevodu, uvijek trebala donijeti nešto novo u sustav književnosti primateljice, jasno je da to ovdje nije slučaj. Prevođenje na ovaj način ne uspijeva ispuniti, ako već ne izdaje, svoju primarnu funkciju.

U ovom kontekstu valja promotriti što se dogodilo s tekstom Maje Hrgović. Može se reći da je prijevod ove priče istovremeno ušao u novu kulturu, u novi sustav ili polisistem i ostao izvan njih. Naime, ovako sagledan ključ po kojem je Zlatka izabrana za antologiju Best European Fiction 2012 omogućava priči i autorici ulazak u sistem književnosti u prijevodu na engleski jezik, što samo po sebi podrazumijeva ulazak u sistem svjetske književnosti i time je prijevod ispunio svoju svrhu. Međutim, taj isti ključ onemogućava adekvatno čitanje djela kao primjera kvalitetne književnosti općenito, ali i kao primjera kvalitetne hrvatske književnosti koji se može mjeriti s djelima slične tematike koja dolaze iz drugih književnosti i koji upravo zbog toga, a ne zbog činjenice da 
odgovara određenom ključu, odnosno, da se može uklopiti u određenu ovjerenu i kanoniziranu kategoriju ili da odgovara određenom ideološkom svjetonazoru, zaslužuje da bude preveden na strani jezik. U tom smislu prijevod nije uspio ispuniti svoju svrhu. Nadalje, taj isti ključ onemogućava uspostavljanje odnosa između ovog djela i ostalih djela u prijevodu s još neprevedenim djelima hrvatske književnosti. Sagledan iz ovakve perspektive, iz ovakvog ključa, taj prijevod načelno ne donosi ništa novo u kulturu primateljicu, već samo dopunjava postojeće. Isto tako, ovaj prijevod ne govori ništa novo o hrvatskoj književnosti, ne otkriva novu stranu hrvatske književnosti, što je zapravo paradoksalno jer Maja Hrgović predstavlja novu stranu hrvatske književnosti, i ne otvara prostor za prijevode novih djela. Ponavljam, ovdje nije upitno da je priča Maje Hrgović, kao i djela ostalih autorica i autora spomenutih u ovom radu, primjer kvalitetne književnosti, baš kao što nisu upitne namjere urednika i svrha same antologije, već se ovdje radi o pitanjima selekcije, kategorizacije, percepcije i recepcije djela u prijevodu, odnosno, o nametnutom i trenutačno dominantnom ključu po kojem se djela hrvatske književnosti, svjesno ili nesvjesno, biraju za prijevod, i o pitanju svrhe prevođenja ovog teksta: zašto prevoditi nešto što već postoji u kulturi primateljici, nešto što je u njoj "isto” jer u potpunosti odgovara već uspostavljenim očekivanjima? I koje su posljedice takvog prevođenja za kulturu primateljicu, ali i izvornu kulturu i autore uključene u proces. Ne bi li bilo bolje da u ovakvoj antologiji kratka priča Maje Hrgović, oslobođena ključa po kojem se čita hrvatska književnost i po kojem se odabire za prijevod, stoji kraj drugih tekstova s ovih prostora, a onda i kraj drugih tekstova raznih europskih književnosti koji nude drukčije viđenje svijeta, kulture, ideologije, politike i koji su prije svega primjeri vrhunskog spisateljskog umijeća? Ne bi li na taj način prijevod ispunio svoju svrhu i u kulturu i književnost primateljicu unio nove načine promišljanja stvarnosti i svijeta oko sebe, pretočio, riječima Willisa Barnstonea, strani sadržaj u domaći oblik, uveo nove stilske i poetičke postupke i strategije te tako obogatio kulturu i književnost primateljicu i u njoj, ali i u izvornoj kulturi, potaknuo neke nove procese i gibanja unutar književnih polisustava? Odgovor na ova pitanja bez sumnje je potvrdan.

\section{Bibliografija}

Sada se nameće pitanje koja je posljedica ovakvog stanja. lako je iluzorno očekivati da je bilo koja književnost u prijevodu zastupljena u potpunosti, odnosno, da u prijevodu na strani jezik postoje djela koja mogu ponuditi presjek cjelokupne suvremene književne produkcije neke nacionalne 
književnosti ili da se razvoj i kontinuitet zbivanja na nekoj nacionalnoj književnoj sceni mogu pratiti s kakvom-takvom recentnošću, u slučaju hrvatske književnosti u prijevodu na engleski jezik, osobito u slučaju kanonizirane, očito je vrlo veliko odstupanje od stvarnog stanja u hrvatskoj književnosti. Naravno, odstupanje i određeni odmak kod književnosti u prijevodu uvijek postoje nemoguće je očekivati da će sva djela biti prevedena niti sva djela mogu biti prevedena na strani jezik; neka su, naprosto, svojim sadržajem, jezikom, itd. previše lokalna i možda uopće nisu upućena na stranu publiku - no dominantni trendovi na recentnoj hrvatskoj književnoj sceni ipak upućuju na ponešto drukčiju situaciju od one koju imamo u prijevodu. Ne može se reći da hrvatskom književnom scenom dominira isključivo ratna tematika, a premda se možda ipak može, barem ako je suditi po posljednjoj književnoj godini, primijetiti dominacija ženskih autorica, ipak je teško povjerovati da je poklapanje domaće i prijevodne situacije na primjeru Maje Hrgović tek više od slučajne podudarnosti.

Nadalje, ovdje se radi o nemogućnosti adekvatne valorizacije prevedenog teksta, odnosno vrijednost teksta Maje Hrgović ne može se adekvatno ocijeniti zato što se on ne može ni pročitati u pravom kontekstu jer je kontekst takav da je hrvatska književnost - doduše, samo u prijevodu, ali prijevodi su slika stanja na izvoru, ili bi to trebali biti - barem kad je u pitanju broj dostupnih prijevoda recentnih djela, a to je, ne smijemo biti u zabludi, sve što i spomenuti malobrojni stručnjaci (naravno, ne oni iz Hrvatske, premda oni iz Hrvatske znaju malo o stanju svoje književnosti u prijevodu) znaju o hrvatskoj književnosti, ograničena na kontekst "ratne" književnosti. Spomenuto podomaćivanje na višoj razini, odnosno, podomaćivanje prilikom selekcije, kategorizacije, percepcije i recepcije djela u kulturi primateljici ili pak, kao što to navode Lefevere i Bassnett, ponovno upisivanje (re-writing) određenog djela u kulturu primateljicu, odnosno, manipulacija njime pod utjecajem različitih hegemonistički obilježenih čimbenika, omogućeni su veličinom književnosti, odnosno, prema Even-Zoharu njenim položajem unutar polisistema prijevodne književnosti. Naime, književnost u prijevodu s hrvatskog jezika, ako ne i književnost u prijevodu općenito, ima rubnu poziciju u polisistemu angloameričke književosti te je stoga, kako u činu prevođenja (osobito ako se radi o stranim, ne-hrvatskim prevoditeljima) tako i u procesu prevođenja, izložena prihvaćanju nametnutih, ali možda već i u domaćem polisustavu odbačenih normi. Dakle, da pojasnim, prevode se ona djela koja na određeni način već postoje u polisistemu, 
odnosno, ona djela koja već imaju utvrđeno mjesto u sustavu i ni na koji način u njemu ne pokušavaju narušiti ravnotežu ili uspostavljenu hijerarhiju. Na taj način, takva djela podržavaju domaći sustav, u njega, načelno, ne unose ništa novo, istovremeno sprečavajući da novina iz strane književnosti prodre u domaći sustav i izazove promjenu. Premda bi strana književnost, odnosno, književnost u prijevodu, uvijek trebala donijeti nešto novo u sustav književnosti primateljice, jasno je da to ovdje nije slučaj. Prevođenje na ovaj način ne uspijeva ispuniti, ako već ne izdaje, svoju primarnu funkciju.

U ovom kontekstu valja promotriti što se dogodilo s tekstom Maje Hrgović. Može se reći da je prijevod ove priče istovremeno ušao u novu kulturu, u novi sustav ili polisistem i ostao izvan njih. Naime, ovako sagledan ključ po kojem je Zlatka izabrana za antologiju Best European Fiction 2012 omogućava priči i autorici ulazak u sistem književnosti u prijevodu na engleski jezik, što samo po sebi podrazumijeva ulazak u sistem svjetske književnosti i time je prijevod ispunio svoju svrhu. Međutim, taj isti ključ onemogućava adekvatno čitanje djela kao primjera kvalitetne književnosti općenito, ali i kao primjera kvalitetne hrvatske književnosti koji se može mjeriti s djelima slične tematike koja dolaze iz drugih književnosti i koji upravo zbog toga, a ne zbog činjenice da odgovara određenom ključu, odnosno, da se može uklopiti u određenu ovjerenu i kanoniziranu kategoriju ili da odgovara određenom ideološkom svjetonazoru, zaslužuje da bude preveden na strani jezik. U tom smislu prijevod nije uspio ispuniti svoju svrhu. Nadalje, taj isti ključ onemogućava uspostavljanje odnosa između ovog djela i ostalih djela u prijevodu s još neprevedenim djelima hrvatske književnosti. Sagledan iz ovakve perspektive, iz ovakvog ključa, taj prijevod načelno ne donosi ništa novo u kulturu primateljicu, već samo dopunjava postojeće. Isto tako, ovaj prijevod ne govori ništa novo o hrvatskoj književnosti, ne otkriva novu stranu hrvatske književnosti, što je zapravo paradoksalno jer Maja Hrgović predstavlja novu stranu hrvatske književnosti, i ne otvara prostor za prijevode novih djela. Ponavljam, ovdje nije upitno da je priča Maje Hrgović, kao i djela ostalih autorica i autora spomenutih u ovom radu, primjer kvalitetne književnosti, baš kao što nisu upitne namjere urednika i svrha same antologije, već se ovdje radi o pitanjima selekcije, kategorizacije, percepcije i recepcije djela u prijevodu, odnosno, o nametnutom i trenutačno dominantnom ključu po kojem se djela hrvatske književnosti, svjesno ili nesvjesno, biraju za prijevod, i o pitanju svrhe prevođenja ovog teksta: zašto prevoditi nešto što već postoji u 
kulturi primateljici, nešto što je u njoj "isto” jer u potpunosti odgovara već uspostavljenim očekivanjima? I koje su posljedice takvog prevođenja za kulturu primateljicu, ali i izvornu kulturu i autore uključene u proces. Ne bi li bilo bolje da u ovakvoj antologiji kratka priča Maje Hrgović, oslobođena ključa po kojem se čita hrvatska književnost i po kojem se odabire za prijevod, stoji kraj drugih tekstova s ovih prostora, a onda i kraj drugih tekstova raznih europskih književnosti koji nude drukčije viđenje svijeta, kulture, ideologije, politike i koji su prije svega primjeri vrhunskog spisateljskog umijeća? Ne bi li na taj način prijevod ispunio svoju svrhu i u kulturu i književnost primateljicu unio nove načine promišljanja stvarnosti i svijeta oko sebe, pretočio, riječima Willisa Barnstonea, strani sadržaj u domaći oblik, uveo nove stilske i poetičke postupke i strategije te tako obogatio kulturu i književnost primateljicu i u njoj, ali i u izvornoj kulturi, potaknuo neke nove procese i gibanja unutar književnih polisustava? Odgovor na ova pitanja bez sumnje je potvrdan. Barnstone, Willis. "An ABC of Translating Poetry“ iz The Poetics of Translation: History, Theory, Practice. New Haven-London: Yale University Press, 1993. (dostupno na www.poets.org) Bassnett, Susan i Lefevere, Andre, ur. Constructing Cultures: Essays on Literary Translation. Bristol i Clevedon: Multilingual Matters, 1998.

Freeman, John, ur. Granta 115: The F Word (Feminism). Granta: the Magazine of New Writing. London: Granta Publications, 2011. 
[1] Da situacija ipak nije tako blistava svjedoči primjer prijevoda teksta Mime Simić koji je doslovno "izmasakriran", a da autorica, ujedno i prevoditeljica, nije bila konzultirana o promjenama koje su unešene u tekst. Više o ovom slučaju: Simić, Mima. "The Facts Behind One Story in Dalkey Archive”s Best European Fiction for 2011.“" Three Percent. veljača 2011.

[2] Između redaka, međutim, dade se iščitati da su djela u prijevodu često okarakterizirana i predstavljena kao eksperimentalna proza premda takva ne moraju biti u izvorniku. Npr. Dalkey Archive je objavio knjigu Vedrane Rudan Uho, grlo, nož koja se ipak, barem po mom mišljenju, ne bi mogla svrstati u kategoriju "eksperimentalne proze".

[3] Pritom "ratnu" tematiku treba shvatiti prilično uvjetno. Ovo jesu djela koja većinom govore o posljednjem ratu na području bivše Jugoslavije, o njegovim posljedicama, o raspadu Jugoslavije kao zajedničkog, multinacionalnog projekta, o socijalizmu, komunizmu i njihovim dosezima, itd. no ona sa sobom donose i određeni ideološki i politički predznak. Ta djela su najvećim dijelom pisana u anacionalnom ključu i svako spominjanje nacionalnih odrednica u njima je negativnog predznaka, dakle, to su djela koja su u svakom smislu protiv nacionalizma i ostalih zala koja je taj sukob iznjedrio ili koja su mu prethodila.

[4] lako je, najšire rečeno, "žensko pismo" obilježilo početke njihovih spisateljskih karijera te unatoč činjenici da se u svojim najnovijim naslovima ipak vraćaju sličnim "ratnim" temama

[5] Naravno, moguće je primijetiti da je broj članova zajednice limitiran i brojem prijevoda, odnosno, njihovom tematikom. Također je moguće da taj broj nije veći upravo zbog spomenute tematike djela koja postoje u prijevodu te da takva književnosti jednostavno odbija određeni broj čitatelja u koje valja ubrojiti i stručnjake koji bi se takvom književnošću bavili.

[6] Dijaspora, bez obzira radi li se o hrvatskoj ili nekoj drugoj dijaspori snažnog nacionalnog predznaka ili pak o dijaspori koja odbija takav predznak te se može smatrati bivšom jugoslavenskom dijasporom, predstavlja posebnu zajednicu koju valja posebno istražiti i koja sa sobom nosi neke druge probleme političkog i ideološkog upisivanja u prijevod, no za takvo istraživanje ovdje, nažalost, nema dovoljno prostora. 
[7] Naravno, i takva djela mogu biti prevedena - nema djela koje je neprevodivo - no postavlja se pitanje svrhe takvih prijevoda, osobito u slučaju izostanka istraživačkih centara ili akademskih institucija kojima bi takva djela i takvi prijevodi mogli biti zanimljivi za proučavanje.

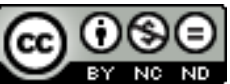

Creative Commons Attribution-NonCommercial-NoDerivatives 4.0 International License 